\title{
ON ELONGATED RIDGES OF DRIFT, 1N BERWICKSHIRE AND OTHER PARTS OF THE SOUTH OF SCOTLAND.
}

\author{
By Mr. Milse-Hose, F.G.S.
}

Mr.Milne-Home described several examples of these "Kaims" in Berwickshire, Roxburghshire, and other places. He stated that they were so regular as to have the appearance of railway-embankments or fortifications, and that they had often been mistaken for the latter. They were from forty feet to sixty feet in height, and sometimes could be traced for three or four miles. They were found at various heights above the sea up to seven hundred and fifty feet. In examining their internal structure they were scen to consist generally of sand, gravel, and boulders; the latter generally rounded, but also occasionally angular. He adverted to the fact that they are sometimes intersected by rivulets and even rivers, but that notwithstanding this they had all the appearance of having, been when originally formed, continuous. The author offered some remarks on the agency supposed to have been concerned in the production of these "kaims." He repudiated the notion of their formation by glaciers. He considered they were due to the action of water, as indicated by their internal structure; and mpposed that they must have been formed by the waters of the ocean when they stood at least eight hundred fcet above its present level. The only question, as he thought, was whether they had been thrown up as submarine spits or banks, or whether they had becu formed by a process of scooping out, when the land emerged from the ocean. His opinion wavered between these two views, but he was inclined to favour the last, as he thought that the violent action of tides and currents was incousistent with the lajers of finc sand which frequently occurred in the kaims.

\section{REMARKS ON THE TEMPERATURE OF THE EARTH'S CRUST, AS EXHIBITED BY THERMOMETRICAL RETURNS OBTAINED DURING THE SINKING OF THE DEEP MINE AT DUKINFIELD.}

$$
\text { By Wu. Fambairx, Eeq., LL.D., F.R.S. }
$$

Wm. Fairbairn, Esq., LL.D., F.R.S., said--It is now more than ten ycars since a series of experiments was commenced to determine the temperature at which certain substances became fluid under pressure. 'These experiments had reference to the density, point, of fusion, atd conducting power of the unatcrials of which the earth's crust is composed, and were prosecuted with a view to the solution of some questions regarding the probable thickness of the earth's crust. Contemporaneously with these, we were fortunate in being able to ascertain by direct experiments, under very farourable circumstances, the increase of temperature in the earth's crust itself. These observations were obtained by means of thermoneters placed in bore-lioles at varions deptlss, during the sinking of one of the deepest mines in England, the coal-mine belonging to E. D. Astley, Esq., at Dukinfield. 'The bore-holes were driven to such a depth as to be unaffected by the temperature in the shaft, and tho thermometers were left in them for periods varying from half an hour to two lours. It is very difficult to arrive at accurate data on the subject of the 
increaso of temperature in the earth's crust. The cxperinents hitherto made give, unfortunately, somcwliat conflicting results, and even in the same mine the rate of increase of temperature is by no means uniform. This is shown very clearly in the results obtained by $\mathrm{Mr}$. Astley. It is scarcely probable, however, that the temperature in the mine-shaft influenced the results, and we must therefore seek the cause of this irregularity in the varying conducting power of the different strata, arising from different density, and different degrees of moisture of the strata. As to the rate of increase, they appear to confirm previous experiments, in which it has been shown that the temperature increases directly as the depth. The rate is at first rather less than this, afterwards somewhat greater, and at last again less, but on the whole. the straiglit line on which the temperature increases as the depths nearly ex presses the mean of the experiments. The amount of increase indicated in these experiments is from 51 degs. to $57 \frac{3}{4}$ degs., as the depth increases from $5 \frac{2}{3}$ yards to 231 yards, or an increase of $1 \mathrm{deg}$. in 99 feet. But if we take the results which are more reliable, namely those between the depths of 231 and 685 yards, we have an increase of temperature from $577^{\frac{3}{3}}$ degs. to $75 \frac{1}{2}$ degs., or $17 \frac{\mathrm{a}}{4} \mathrm{degs}$. Falirenheit. That is a mean increase of $1 \mathrm{deg}$. in 76.8 feet. This rate of increase is not widely different from that discovered by other authorities. Walferdin and Arago found an increase of $1 \mathrm{deg}$. in 59 feet in the artesian well at Grenelle. At the saltworks at Rheme, where an artesian well penetrates to a depth of 760 yards, or rather more than the Dukinfield mine, the increase is 1 deg. in 54.7 feet. MM. de la Rive and Marcet found an increase of $1 \mathrm{deg}$. in 71 feet. In one respect the observations in the Dukinfield mine are peculiarly interesting. As they give the temperature in various descriptions of rock, they appear to prove what has hitherto been partially suspected, namely, that the conducting powers of the rocks exercise a considerable influence on the temperature of the strata. If we add to this the influence of the percolation of water, we shall probably have a sufficient explanation of the irregularities observed in the experiments. From the above observations we have evidence of the existense in the earth of a central heat, the temperature, so far as can be ascertainee, increasing in the simple ratio of the depth. We do not, however, prestume to offer an opinion as to whether this increase continues to infinitely greater depths than we have yet penetrated, as observatious upon this point are still imperfect. But, assuming as an hypothesis, that the law which prevails to a depth of 700 vards continues to operate at still greater depths, we arrive at the conclusion that at a depth of less than two and a lalf miles the temperature of boiling water would be reached, andat a depth of 40 miles a temperature of 3,000 degs. Fahrenheit, which we may assume to be sufficient to melt the most refractory rocks of which the earth's crust is composed. If, therefore, no other circumstance modifed the conditions of liquefaction, all within a thin crust of this thickness would be in a fluid state. This, however, is not the case. At these depths the fusing point is modified by the pressure and conductivity of the rocks. We know that in volcanic districts, where the great subterranean laboratory of nature is partially opened for our inspection, the molten mass, relieved from pressure, pours forth from volcanic craters currents of lava which form a peculiar class of rocks. Besides this, it has been ascertained from Mr. Hopkins's experiments on soft substances, such as spermaceti, wax, and sulphur, that the temperature of fusion increases about 1.3 Farenheit for ever $500 \mathrm{lb}$. pressure per square inch, that is, in other words, that the temperature of fusion under pressure is increased in that ratio. If we assume this to be the law for the materials of the earth's crust, and correct our previous calculations in accordance with it, we shall find that we have to go to a depth of 65 miles, instead of merely 40 , before the point of fusion of the rocks is reached. It must, thcrefore, be observed that $\mathrm{Mr}$. Hopkins's later experiments with tin 
and barytes, do not show such an increase of the point of fusion in consequence of pressure, and he is led to the belief that it is only in the more compressible substances that the law loolds true. Independently of this, howerer, Mr. Hopkins points out to me that in the above calculation it is assumed that the conductivity of the rocks is the same at great depths as at the surface. In opposition to this he has shown experimentally that the conducting power for heat is at least twice 29 great for the dense igneous rocks as for the more superficial sedinentary formations of clay, sand, chalk, \&c. And these closegrained igneous rocks are those which we believe must most resemble the rocks at great depths below the surface. Now Mr. Hopkins shows that if the conductive power were doubled, the increase of depth, corresponding to a given increase of temperature, would be doubled, and we should probably have to descend 80 or 190 miles to reach a temperature of 3,000 degrees, besides the further increase which investigation may show to be due to the influence of pressure on the temperature of fusion. Mr. Hopkins therefore concludes that the extreme thinness of the crust assumed by some geologists to account for volcanic phenomena is untenable. Calculations on entirely independent data led him to conclude that the thickness did not fall short of s00, instead of 30 or 40 miles. If it be so much, he is further led to believe that the superficial temperature of the crust is due to some other cause than an internal fluid of nucleus. It remains a problem, therefore, which my friend, Mr. Hopkins, is endeavouring to solve, as to what is the actual condition of the earth at great de',ths, and the relation of terrestrial heat to volcanic phenomena.

Mr. W. Hopkins considered the paper of Dr. Pairbairn merited more confidence than any which had before been given to the public; for no previous communication had so largely taken into accoint the various circumstances in connection with deep mines, which bore on the temperature of the earth's crust. The condition of the rocks and walls, as well as the water in mines, must necessarily have a varying effect upon the temperature; and these facts had not previously received sufficient attention at the liands of those who had made experiments. One great advantage of the experiments recorded by the President of the Association was that they were made in a mine before it had been worked. The strata of Dukinfield mine were very much inclined, and there was a good deal of water in it. For this reason great cantion was needed in working it, because a wet mine gave a higher degree of temperature than a dry mine. Hitherto there had been great difficulty in making observations and experiments in mines. Dr. Fairbairn supposed that 3,000 degrees might be the temperature of fusion. It night be greater for all they knew. He should be inclined to think it was greater. $\Lambda$ thickness of 800 or 1,000 miles for the crust of the earth was more consistent with his own observations, and ho positively insisted on a greater depth than 100 or 200 miles.

\section{VELOCITY OF EATTHQUAKE.IVAVES.}

By R. MaI.t.FT, Esq, F.G.S.

The experiments which were conducted at the large blasting-operations at Holyhead were undertaken at the joint request of the Royal Society and the British Association. Mr. Mallett confessed that a few ycars ago lie was under the impression that the velocity of the wave-particle of an earthquake, though not the same as the wave-transit, was nearly equal to it. It was only 